DOI: https://doi.org/10.32839/2304-5809/2021-4-92-54

уДК 343.1

Ільченко О.В., Корощенко К.Р.

Сумський державний університет

\title{
АКТУАЛЬНІ ПИТАННЯ ШОДО ВІДШКОДУВАННЯ ШКОДИ, ЗАВДАНОЇ ВНАСЛІДОК ВЧИНЕННЯ КРИМІНАЛЬНОГО ПРАВОПОРУШЕННЯ
}

\begin{abstract}
Анотація. Захист громадян України є одним із завдань держави, визначені в Конституції України та інших нормативних актах. Відновлення порушених прав також вважається захистом громадян. Майнова або моральна шкода є серйозними наслідками кримінального правопорушення, які можна відновити, довівши наявність такої шкоди. Проте, законодавство містить низку прогалин, які вимагають вирішення та редормування. Стаття присвячена дослідженню функціонування процесу відшкодування завданої шкоди потерпілому. А також виявленню проблем, які існують на даний час. Чітке визначення прогалин у законодавчому закріпленні механізму відшкодування майнової та моральної шкоди, а також конкретне окреслення проблем при процесуальному захисті прав громадянина допоможуть знайти шляхи вирішення цим проблемам.
\end{abstract}

Ключові слова: кримінальне провадження, судочинство, майнова шкода, матеріальна шкода, відшкодування, поновлення прав.

Ilchenko Oleksandr, Koroshchenko Kateryna Sumy State University

\section{CURRENT ISSUES REGARDING COMPENSATION FOR DAMAGES CAUSED AS A RESULT OF A CRIMINAL OFFENSE}

Summary. Protection of citizens of Ukraine is one of the tasks of the state, defined in the Constitution of Ukraine and other regulations. Restoration of violated rights is also considered protection of citizens. Property or non-pecuniary damage is a serious consequence of a criminal offense that can be remedied by proving the existence of such damage. However, the legislation contains a number of gaps that need to be addressed and reformed. The article is devoted to the study of the functioning of the process of compensation for damage to the victim. As well as identifying problems that currently exist. A clear definition of gaps in the legislative consolidation of the mechanism of compensation for property and moral damage, as well as a specific outline of problems in the procedural protection of civil rights will help to find ways to solve these problems. The article also examines the topic of the application of civil lawsuits in criminal proceedings in more detail, as well as outlines the problems in its application. A civil lawsuit may be filed by a person who has suffered property and / or moral damage by a criminal offense or other socially dangerous act, has the right to file a civil lawsuit against a suspect, accused or natural or legal person during criminal proceedings prior to the trial. The law is civilly liable for damage caused by the actions of a suspect, accused or insane person who has committed a socially dangerous act. The problem of a very large number of paper documents required of a civil plaintiff is described. In Ukraine, there is also a problem with proving non-pecuniary damage, which is very difficult to prove, scientists have proposed a formula for calculating non-pecuniary damage to victims. Also, the issue of ensuring compensation to the victim at the expense of the state remains controversial and requires both research and legislative regulation. After all, if voluntary compensation to the victim or its recovery based on the results of a civil lawsuit is enshrined in the criminal procedure legislation of Ukraine, the issues of grounds, conditions and procedure for compensation from the State Budget of Ukraine are poorly studied and need to be enshrined in domestic law.

Keywords: criminal proceedings, legal proceedings, property damage, material damage, compensation, restoration of rights.

$\prod$ остановка проблеми. Кожний потерпів Україні мае право на відшкодування майнової та моральної шкоди, проте існуе ряд проблем, які потребують дослідження та негайного вирішення, а саме недостатне законодавче регулювання питань щодо доведення та відшкодування моральної шкоди, відсутність спеціального нормативно-правового акту за допомогою якого можна було б визначити розмір моральної шкоди, запровадити формулу розрахунку моральної шкоди потерпілим. Питання забезпечення відшкодування шкоди потерпілому за рахунок держави також залишаеться суперечливим і вимагае як наукових досліджень, так і законодавчого регулювання.

Аналіз останніх досліджень та публікацій Питанню дослідження фрункціонування механізму відшкодуванню завданої шкоди у кримінальному провадженні приділяли достатньо уваги в наукових публікаціях та статтях, зокрема, такі українські вчені як В. В. Батуєв, Т. Р. Галімов, Ю. М. Грошовий, В. В. Дубровін, О. В. Капліна, С. В. Кравцова, Ю. В. Курдубанов, Е. Ф. Куцова, О. П. Кучинський та інші.

Раніше не вирішеними проблемами $е$ визначення основних проблем щодо відшкодування майнової та моральної шкоди в кримінальному судочинстві.

Метою даної статті є провести дослідження механізму функціонування відшкодування завданої шкоди у кримінальному провадженні, виявити основні проблеми та шляхи їх вирішення.

Виклад основного матеріалу. Відшкодування шкоди, завданої внаслідок правопорушення - важлива складова захисту громадян будь-якої демократичної держави. Україна позиціонуе себе як демократична держава, яка всіма приписами у законодавчих актах проголошуе піклування та забезпечення повного захисту всіх українців. 
Перший законодавчий акт у якому можна знайти законодавче закріплення гарантування громадянину захист - ст. 3 Конституції України, яка

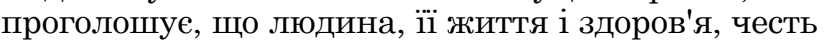
і гідність, недоторканність і безпека визнаються в Україні найвищою соціальною цінністю. Права і свободи людини та їх гарантії визначають зміст і спрямованість діяльності держави. Держава відповідае перед людиною за свою діяльність [1].

Кримінально-процесуальний закон виокремлюе дві основі форми завданої шкоди: злочинний результат і злочинні наслідки. Інститут відшкодування завданої шкоди є важливою складовою будьякого процесу в Україні. Важливість відшкодування завданої шкоди також прописана в Конституції України, а саме в статті 56: кожен має право на відшкодування за рахунок держави чи органів місцевого самоврядування матеріальної та моральної шкоди, завданої незаконними рішеннями, діями чи бездіяльністю органів державної влади, органів місцевого самоврядування, їх посадових і службових осіб при здійсненні ними своїх повноважень [1].

Досліджувана тема стосуеться саме відшкодування моральної чи майнової шкоди у кримінальному процесі. Як і у будь-якому механізмі захисту прав громадянина існує ряд проблем, які можливо вирішити. Проте, перш ніж виявити проблеми у відшкодуванні моральної чи майнової шкоди у кримінальному процесі необхідно визначити, як саме український законодавець визначає моральне та майнове відшкодування шкоди.

Моральною шкодою визнаються втрати, які мають немайновий характер. Моральна шкода полягає в отриманні моральних страждань, психічних розладів, які впливають на подальше життя та працездатність потерпілої особи. А також психологічні відхилення, які особа отримала внаслідок вчинення кримінального правопорушення. Моральна шкода згідно з українським законодавством може бути відшкодована грошима або майном. Доказати наявність моральної шкоди дуже важко, але можливо.

Серед науковців, які детально досліджували поняття шкоди, завданої злочином, $є$ й такі, що повністю заперечують виникнення (завдання) моральної шкоди потерпілій особі, так Татарин I. I. не вважає можливою постановку питання про відшкодування в кримінальному процесі заподіяної злочином моральної шкоди (збитків), хоча б з одніеї лише причини неможливості їі грошового вираження [2]. Проте, сучасна думка науковців щодо відшкодування саме моральної шкоди дуже змінилась, на сьогоднішній день український законодавець регламентує процес відшкодування моральної шкоди.

Майновою шкодою $е$ зменшення кількості та якості наявного майна у особи, внаслідок знищення або пошкодження особою, яка здійснила кримінальне правопорушення. Згідно з чинним законодавством майнова шкода має бути відшкодована у повному обсязі потерпілій особі. Доказати майнову втрату набагато легше ніж моральну. Проте потерпіла особа має надати всі докази того, що дійсно втратила майно внаслідок кримінального правопорушення.

Вперше в Кримінальному процесуальному кодексі України зустрічаємо згадування про відшкодування шкоди у п. 10 ч. 1 ст. 56 , яка визначає права потерпілого і саме у цьому переліку зазначено, що потерпілий має право на відшко- дування шкоди, завданої внаслідок кримінального правопорушення [3].

Надалі в КПК визначення відшкодування завданої шкоди білыш широко знайшло своє тлумачення у ст. 127 , яка визначає, що фрізична чи юридична особа має право на будь-якому етапі кримінального провадження відшкодувати завдану шкоду потерпілому, територіальній громаді, державі внаслідок кримінального правопорушення [3].

Взагалі ст. 127 КПК визначає три способи відшкодування шкоди завданої кримінальним правопорушенням, кожний наступний застосовується при неможливості застосування попереднього.

Перший - добровільна згода обвинуваченого відшкодувати завдану шкоду, про фріксацію ціеї згоди має бути відповідний документ у матеріалах справи.

Другий спосіб заключається у відшкодуванні завданої шкоди шляхомрозгляду цивільного позову у кримінальному судочинстві [3].

Третій спосіб відкшодунная шкоди, полягає у компенсації потерпілому шкоди державою за рахунок Державного бюджету [3].

Доречно більш детально розглянути застосування інституту цивільного позову у кримінальному судочинстві та окреслити основні проблеми щодо його розгляду. Цивільний позов може подавати особа, якій кримінальним правопорушенням або іншим суспільно небезпечним діянням завдано майнової та/або моральної шкоди, має право під час кримінального провадження до початку судового розгляду пред'явити цивільний позов до підозрюваного, обвинуваченого або до фрізичної чи юридичної особи, яка за законом несе цивільну відповідальність за шкоду, завдану діяннями підозрюваного, обвинуваченого або неосудної особи, яка вчинила суспільно небезпечне діяння [4].

Як зазначає В. Бараняка, важливою перевагою значення цивільного позову $є$ те, що він забезпечує швидке відновлення майнових прав потерпілого; унеможливлюе прийняття судом суперечливих рішень з того самого питання; дає можливість звільнити підсудного, потерпілого й інших суб'єктів (свідків, експертів тощо) кримінального процесу від необхідності двічі брати участь у судовиробнищтві; а також правильно кваліфікувати злочинну дію.

На його думку проблема застосування цивільного позову починається у ч. 4 статті 128 КПК зміст ціеї норми полягає в тому, що цивільний позов має бути написаний саме за вимогами Цивільного законодавства, дуже часто форма та заміст не відповідають всім вимогам та правилам, адже деяким потерпілим досить незрозуміло як два процеси можуть поєднатись в одному кримінальному провадженні. Тому виникають помилки при оформленні позовної заяви [4].

Наступна проблема полягає в тому, що відповідно до ч. 5 ст. 128 цивільний позов розглядається згідно 3 Кримінальним процесуальним кодексом України, а ті питання, які не регулюе даний кодекс має регулюватись Цивільним процесуальним кодексом [3]. Звісно що, вимоги до написання позовних заяв відрізняються, тому вважаємо потрібним зазначити основна відмінності у кримінальному судочинстві: непередбачена можливість подання зустрічного позову у кримінальному судочинстві; у цивільному позові необов'язково зазначити Відповідача, адже на момент написання заяви правопорушник може бути не встановлений; підставою 
для відкладення розгляду цивільного позову в кримінальній справі не може бути неявка цивільного відповідача чи його представника у засіданні [4].

Важливою особливістю є те, що ані в Цивільному процесуальному кодексу, ані в Кримінальному кодексу не передбачаеться можливості подальшого доповнення та уточнення позовних вимог.

Згідно ч. 5 ст. 177 ЦПК, позивач зобов'язаний додати до позовної заяви всі наявні в нього докази, що підтверджують обставини, на яких грунтуються позовні вимоги, проте позивачі дуже часто вважають, що всі докази є в матеріалах справи і тому додавати нічого потрібно, через цю причину цивільний позов залишають без руху [3].

Стебелев А. М. вважае, що норма КПК щодо вимоги до цивільного позивача додати до позовної заяви її копії та копії всіх доданих до неї документів у кількості підозрюваних/обвинувачених і цивільних відповідачів для вручення кожному з них. Під час кримільного провадження сторони цивільного позову мають право ознайомлюватися 3 матеріалами досудового розслідування після їх відкриття, зокрема й позовною заявою та доданими до неї документами, робити з них копї, виписки, тощо. Це право вони також мають після призначення справи суддею до досудового розслідування. Отже, навряд чи $є$ необхідність обтяжувати цивільного позивача (потерпілого) тими формальностями, які властиві цивільному позову в цивільному судовичнстві [5].

Необхідно зазначити, що докази щодо відшкодування моральної чи майнової шкоди є досить серйозною проблемою. Питання з наданням доказів виникають через неуважність правоохоронних органів, недбалість самої потерпілої особи або з перевищеною оцінкою моральних страждань особи, яка вимагає відшкодування.

Слід звернути увагу на те, що існуе форма відшкодування шкоди за рахунок Державного бюджету України, яка закріплена, зокрема, у ст. 56 Конституції України, де зазначено, що кожен має право на відшкодування за рахунок держави чи органів місцевого самоврядування матеріальної та моральної шкоди, завданої незаконними рішеннями, діями чи бездіяльністю органів державної влади, органів місцевого самоврядування, ïx посадових і службових осіб під час здійснення ними своїх повноважень. Хоча така можливість забезпечується не лише КПК України, а й іншими нормативно-правовими актами, зокрема Цивільним кодексом, на практищі зазначені у них норми не мають наразі чітко визначеної процедури та принципу застосування та спрямовують нас на використання спеціального закону, що у чинному законодавстві відсутній. Слід звернути увагу на ч. 2 ст. 130 КПК, де зазначено, що держава, відшкодувавши шкоду, завдану слідчим, прокурором, застосовує право зворотної вимоги до цих осіб у разі встановлення в їхніх діях складу кримінального правопорушення за обвинувальним вироком суду, який набрав законної сили, або дисциплінарного проступку незалежно від спливу строків застосування та дії дисциплінарного стягнення. У такому разі слід звернути увагу на коло осіб, щодо яких держава застосовуе право зворотної вимоги (прокурор та слідчий), а також на умови такого застосування, зокрема наявність у їх діях альтернативного складу: обвинувального вироку суду, що набрав законної сили, або дисциплінарного проступку не- залежно від спливу строків застосування. Аналіз ціеї норми дозволяе зробити висновок, що держава встановила певні фрінансові гарантії та систему захисту від незаконних дій (бездіяльності) слідчих та прокурорів шляхом можливої компенсації [6].

Нерідко коли внаслідок кримінального правопорушення особа отримуе тілесні ушкодження, доводити цей фракт також необхідно. Серед доказів має бути судово-медична експертиза, медична довіпка, а також точна характеристика правопорушника і відсторонення всіх дій, внаслідок яких потерпілий отримав тілесні ушкодження. До доказів пов'язаних 3 тілесними ушкодженнями відносять також чеки на ліки, які співпадають з тими, які лікар зазначив до вживання. Якщо ліки з історії хвороби не співпадають з чеками, то суд не розглядає такі докази. Також має бути підтвердження, що сам хворий сплачував за всі ліки та медичні процедури, які були проведені через правопорушення [4].

Інститут відшкодування моральної шкоди з'явився порівняно нещодавно. Актуальною проблемою відшкодування моральної шкоди є необхідність доказати їі наявність. Нерідко, коли сам позивач або представник позивача завищуе свої вимоги до відповідача щодо відшкодування моральної шкоди. Для того аби все відбувалось на засадах справедливості існують такі законодавчі акти, які регулюють питання відшкодування моральної шкоди: Конституція України, Цивільний кодекс України, Методичні рекомендащіі «Відшкодування моральної шкоди» (лист Міністерства юстищії України від 13 травня 2004 р. № 35-13/797), Постанова Пленуму ВСУ № 4 від 31.03.1995 р. «Про судову практику в справах про відшкодування моральної (немайнової) шкоди» та інші. У цих нормативно-правових актах зазначені особливості визначення моральної шкоди, а також інформацію 3 приводу вирахування моральної шкоди, що також є проблемою у процесу відшкодування шкоди [4].

Відповідно з чинним законодавством моральна шкода може полягати, а саме: у приниженні честі, гідності,ділової репутащї або престижу, моральних переживаннях у зв'язку з ушкодженням здоров'я, страждань у порушенні права власності (зокрема інтелектуальної), прав, які надають споживачам, інших цивільних прав, у зв'язку 3 незаконним перебуванням під слідством і судом, у порушенні нормальних життевих зв'язків через неможливість продовження активного громадського життя, порушенні стосунків з оточуючими людьми, при настанні інших негативних наслідків [7].

Отже, доказами завданої моральної шкоди можуть стати свідчення колег, керівника на роботі, друзів про моральний стан потерпілого. Проте, існують установи, які надають більш кваліфікований висновок з приводу цьго питання. Наприклад, спеціальні експертні установи, які проведуть психологічне дослідження 3 потерпілим, це передбачено Інструкцією про призначення та проведення судових експертиз та експертних досліджень (затверджена наказом Міністерства юстищії України № 53/5 від 08.10.1998) передбачено навіть цілий перелік орієнтовних питань, які в рамках ціеї експертизи можна поставити фрахівцям і відповіді на які можуть стати основною підставою для прийняття судом рішення про задоволення вимоги щодо відшкодування моральної шкоди. Зокрема, співробітники ціеї установи 
надають точну відповідь на питання чи була завдана моральна шкода потерпілій особі, чи взагалі трапилось для неї щось, що може впливати на iї психічний стан та працездатність [8].

Проблемним питання щодо відшкодування шкоди у кримінальному провадженні є відсутність у національному законодавстві Закону, який би регулював питання процесу відшкодування моральної шкоди, а також визначав мінімальний розмір моральної шкоди, яку може отримати особа. Проте існує законопроект № 8396, автори якого пропонують прийняти Закон України «Про регулювання діяльності із визначення моральної (немайнової) шкоди», який передбачає визначення, випадки і порядок експертизи такої шкоди, суб'єктів, які будуть уповноважені надавати такі висновки, тощо, але наразі проект відкликано та знято з розгляду.

Проблема про яку згадувалось раніше - як вирахувати розмір моральної шкоди, О.Дроздовою запропонована «формула успішного відшкодування моральної шкоди»: МШ = (Д + В + H + ПНЗ + ДК $) \mathrm{CP}$, де МШ - це моральна шкода, яка має місце лише у випадку одночасної наявності (суми) таких елементів як: 1) Д - діяння особи, яке має бути таким, що могло привести до моральної шкоди потерпілого; 2) В - вина особи, яка заподіяла шкоду; 3) $\mathrm{H}$ - наслідки у вигляді моральної шкоди, яка була спричинена винним діянням порушника; 4) ПНЗ - причинно-наслідковий зв'язок між діянням винної особи та моральними стражданнями, який підтверджує, що ці страждання були викликані саме протиправними діяннями; 5) ДК - це докази, які необхідно зібрати та подати суду для підтвердження наявності інших елементів; 6) СР - судове рішення, яке поставить остаточну крапку і може вирішити питання як на користь заявника, так і ні, або ж змінити розмір відшкодування [8].

Отже, запропонована формула $є$ досить дієвою для того аби довести той фракт, що моральну шкоду дійсно було завдана.

Раніше згадувалась проблема недосконалості роботи правоохоронних органів, хотілось би визначити ще один аспект, який погіршує ефрективність їх роботи. Йдеться про те, що відсутня взаємодія оперативних підрозділів та органів досудового розслідування. Дуже часто дрібниці, які мають велике значення для слідчого, замовчуються оперативним співробітником [2]. Тому є потреба у поліпшенні комунікації між цими двома органами, які мають співпрацювати між собою.

Висновок. Отже, відшкодування шкоди у кримінальному провадженні є важливим механізмом захисту прав громадян України. У науковій статті зазначенні наявні проблеми, які, на жаль, у џьому механізмі присутні. До таких проблем можна віднести: недостатне законодавче регулювання цих питань, а також відсутність Закону, який би регулював питання відшкодування моральної шкоди, неналежне ставлення до виконання своїх обов'язків співробітниками правоохоронних органів, відсутність комунікації між цими органами, усі ці фрактори негативно впливають на ефективність ї діяльності щодо відшкодування шкоди у кримінальному процесі. Проте вирішити ці проблеми можливо, за умови врегулювання цих питань на законодавчому рівні, адже моральна та майнова шкода завдана постраждалим громадянам має бути справедливо і своєчасно відшкодована.

\section{Список літератури:}

1. Конституція України : Закон України від 28 червня 1996 р. № 254к/96-ВР / Верховна Рада України. Відомості Верховної Ради України. 1996. № 30. Ст. 141.

2. Татарин I.I. Відшкодування шкоди потерпілому, заподіяної кримінальним правопорушенням : дис. канд. фрілос. наук. Львів, 2017. 184 с.

3. Кримінально процесуальний кодекс України : від 18.04.2010 № 4651-VI / Верховна Рада України. Відомості Верховної Ради України. 2013. № 9-10, № 11-12, № 13, ст. 88.

4. Бараняк В., Несімко О. Проблеми відкшодування шкоди у кримінальному проваджені щодо захисту прав потерпілого. Львівський політехнічний университет. 2018. С. 98-102.

5. Стебелев А.М. Проблеми відшкодування (компенсації) шкоди завданої злочином у кримінальному провадженні. Науковий вісник Міжнародного гуманітарного університету. 2015. Випуск 16. Том 2. С. 87.

6. Ситенька О.С. Реалізація права потерпілого на відшкодування шкоди у кримінальному проваджені: окремі питання. Юридичний науковий електронний журнал. 2020. Випуск 8. С. 451-454.

7. Цивільний процесуальний кодекс України від 18.03.2004 p. № 1618-IV. URL: http://zakon5.rada.gov.ua/laws/ show/1618-15

8. Дроздова О. Відшкодування моральної шкоди: як правильно виразити переживання у гривнях? ЛІГА:ЗАКОН. 2018. URL: https://jurliga.ligazakon.net/analitycs/182283_vdshkoduvannya-moralno-shkodi-yakpravilno-viraziti-perezhivannya-u-grivnyakh

\section{References:}

1. The Constitution of Ukraine: Law of Ukraine of June 28, 1996 № 254k/96-VR / Verkhovna Rada of Ukraine. Information of the Verkhovna Rada of Ukraine. 1996. № 30. P. 141.

2. Tatarin I.I. (2017) Compensation for damage to the victim caused by a criminal offense: dis. cand. philos. sciences. Lviv, p. 184.

3. Criminal Procedure Code of Ukraine: dated 18.04.2010 № 4651-VI / The Verkhovna Rada of Ukraine. Information of the Verkhovna Rada of Ukraine. 2013. № 9-10, № 11-12, № 13, p. 88.

4. Baranyak V., Nesimko O. (2018) Problems of compensation in criminal proceedings for the protection of the rights of the victim. Lviv Polytechnic University, pp. 98-102.

5. Stebelev A.M. (2015) Problems of compensation (compensation) for damage caused by a crime in criminal proceedings. Scientific Bulletin of the International Humanities University, issue 16, vol. 2, p. 87.

6. Sutenka O.C. (2020) Realization of the victim's right to compensation in criminal proceedings: some issues. Legal scientific electronic journal, issue 8. Kyiv, pp. 451-454.

7. Civil Procedure Code of Ukraine of March 18, 2004 № 1618-IV. URL: http://zakon5.rada.gov.ua/laws/show/1618-15

8. Drozdova O. (2018) Compensation for non-pecuniary damage: how to properly express the feelings in UAH? LEAGUE:LAW. URL: https://jurliga.ligazakon.net/analitycs/182283_vdshkoduvannya-moralno-shkodi-yakpravilno-viraziti-perezhivannya-u-grivnyakh 